\title{
Taxonomic revision of the Genus Pieris Schrank (Lepidoptera: Pieridae) from India
}

\author{
Jagbir Singh Kirti \\ Department of Zoology \& Environmental Sciences, Punjabi University, Patiala-147002 \\ (Punjab), India \\ Manpreet Kaur* \\ Department of Zoology \& Environmental Sciences, Punjabi University, Patiala-147002 \\ (Punjab) India

\section{Avtar Kaur Sidhu} \\ High Altitude Regional Centre, Zoological Survey of India, Saproon, Solan-173211 (H.P.), \\ India

\section{Navneet Singh} \\ Zoological Survey of India, Prani Vigyan Bhawan, New Alipore, Kolkata-700053 (West \\ Bengal), India \\ *Corresponding author: E. mail: preetpup@gmail.com
}

\author{
Article Info \\ https://doi.org/10.31018/ \\ jans.v12i3.2314 \\ Received: July 5, 2020 \\ Revised: August 2, 2020 \\ Accepted: August 9, 2020
}

\section{How to Cite}

Kirti, J. S. et al. (2020). Taxonomic revision of the Genus Pieris Schrank (Lepidoptera: Pieridae) from India. Journal of Applied and Natural Science, 12(3): 328 - 343.https://doi.org/10.31018/jans.v12i3.2314

\begin{abstract}
The genus Pieris Schrank popularly called as garden whites are economically important species of family Pireridae, comprise 35 species world over and in India is represented by nine species. In the present manuscript, six species of genus Pieris Schrank i.e., i.e. P. brassicae (Linnaeus), P. canidia (Linnaeus), P. deota (de Niceville), P. extensa Poujade, P. melete Menetries and $P$. rapae (Linnaeus) have been treated taxonomically from India. Besides studying morphological characters, their male and female genitalia have been described in details and illustrated for the first time. The diagnosis of the genus and key to species has been updated using genitalic attributes. In the study of genitalia, it has been observed that in the male genitalia of the genus Pieris the uncus is undivided and aedeagus is short and thick, whereas in the female genitalia the signum is bifid and appendix bursae are well developed. In the present work, the male genitalia of scheduled species $P$. deota has been studied and illustrated for the first time. The male and female genitalia of dry season forms and wet season forms of species $P$. melete, and the subspecies and polymorphic forms of species $P$. canidia have been studied and compared. It has been observed that in all forms there were no genitalic variations within the species.
\end{abstract}

Keywords: Dry season form, Female genitalia, Male genitalia, Pieris, Species, Subspecies, Wet season form

\section{INTRODUCTION}

The genus Pieris was reported by Schrank in 1801 with type species Papilio brassicae Linnaeus. It is a cosmotropical genus with maximum diversity in Palearctic region. Presently genus Pieris comprises 35 species globally of which 9 species are reported from India i.e. $P$. ajaka Moore, $P$. brassicae (Linnaeus), $P$. canidia (Linnaeus), $P$. deota (de Niceville), $P$. dubernardi Oberthur, $P$. extensa Poujade, $P$. krueperi Staudinger, $P$. melete Menetries and $P$. rapae (Linnaeus). This genus has been studied by various eminent works from time to time such as Bingham (1907), Verity (1919), Antram (1924), Klots
(1931), Talbot (1939), Leech (1819) and Herman (1971). Klots (1931) illustrated the genitalic attributes of $P$. brassicae and $P$. rapae and Talbot (1939) described the genitalic attributes of genus Pieris. In the present work, the morphological characters, genitalic attributes and the distribution of six species belonging to this genus have been studied. The genitalic attributes of all the species have been studied, illustrated and compared with each other.

\section{MATERIALS AND METHODS}

The adult Pierid butterfly representatives were captured by using the sweeping net from different 
localities of India. The localities from where various species of genus Pieris have been collected are given in Table 1 and Fig. 1

The collected specimens were killed by putting them straight into the insect-killing bottle containing ethyl acetate vapours. The representatives were then transferred to the butter sheet envelops and brought to the laboratory. They were stretched on the stretching board by using entomological pins and then taken out after 4-5 days. The dried specimens tagged with the labels of locality, date of collection, altitude, etc. were preserved in the entomological storage boxes duly fumigated with the naphthalene balls. The representatives were identified on the basis of their morphological characters by consulting literature such as Antram (1924), Bingham (1907), Evans (1932) and Talbot (1939). The pictures of adult members were obtained from the dorsal and ventral sides with a Nikon digital camera $(18-105 \mathrm{~mm})$. Then they were identified by dissecting their genitalia by adopting the method proposed by Robinson (1976). The terminology for the genitalia has been adopted from Klots
(1970). The photography of external genitalia of both the sexes has been accomplished by using Leica microscope equipped with a photographic unit. The Pierid species preserved in the National Museum of Lepidoptera, ZSI, Kolkata have also been studied.

\section{OBSERVATIONS AND DISCUSSION}

\section{Genus Pieris Schrank, 1801}

Common name: Whites

Pieris Schrank, 1801; Fauna Boica 2 (1): 152.

Ganoris Dalman, 1816; K. Vetensk Acad. Handl. (1): 61.

Tachyptera Berge, 1842; Schmetterlingsbuch. 19: 92 $-105$.

Artogeia Verity, 1947; Le Farfalle diurn. d'Italia 3: 192. Talbotia Bernardi, 1958; Rev. franc. Ent. 25: 125.

Type species: Papilio brassicae Linnaeus, 1758 Papilio brassicae Linnaeus, 1758; Syst. Nat. (Edn 10) 1: 467.

Diagnosis: Forewing vein $R_{3}$ arises from vein $R_{5}$ and the fork is more close to the apex of the wing instead of the apex of the cell. Juxta cone-shaped

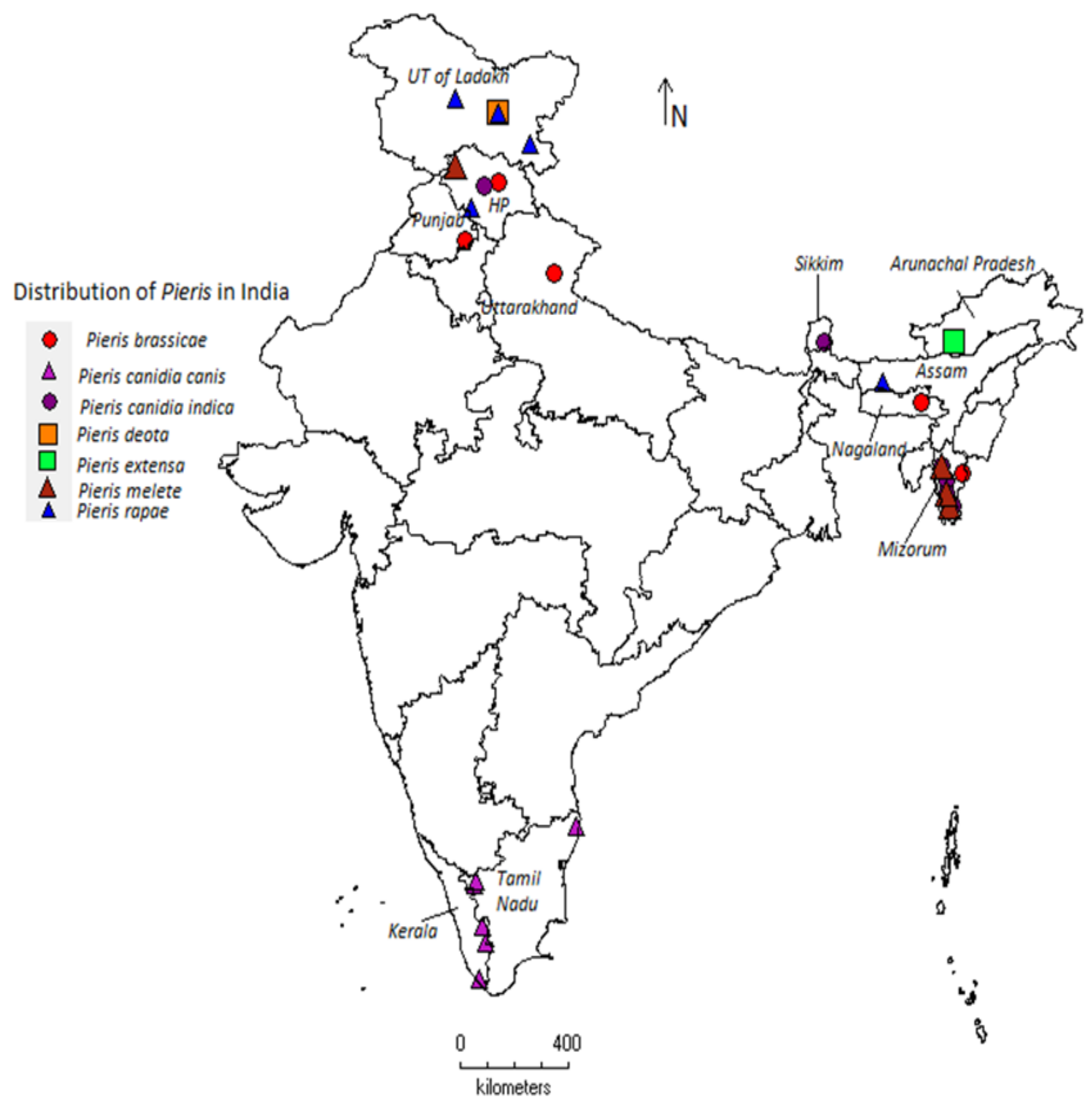

Fig. 1. Distribution of various species of the genus Pieris Schrank in India. 
Kirti, J. S. et al. / J. Appl. \& Nat. Sci. 12(3): 328 - 343 (2020)

Table 1. Collection localities (along with Latitudes and Longitudes) of various species of genus Pieris Schrank from India.

\begin{tabular}{|c|c|c|c|c|}
\hline S. No. & Species & Locality & Latitude & Longitude \\
\hline 1. & Pieris brassicae & Sukha, Nanital & 29.380304 & 79.46357 \\
\hline 2. & Pieris brassicae & Shillong & 25.5788 & 91.8933 \\
\hline 3. & Pieris brassicae & Punjabi University Patiala & 30.359057 & 76.449078 \\
\hline 4. & Pieris brassicae & Thenzawl, Mizoram & 23.2808 & 92.7741 \\
\hline 5. & Pieris brassicae & Lunglei, Mizoram & 22.867069 & 92.765533 \\
\hline 6. & Pieris brassicae & Lawngtlai, Mizoram & 22.528445 & 92.892634 \\
\hline 7. & Pieris brassicae & Champai , Mizoram & 23.4566 & 93.3282 \\
\hline 8. & Pieris brassicae & Reiek, Mizoram & 23.6777 & 92.6037 \\
\hline 9. & Pieris brassicae & Taradevi, H.P. & 32.084206 & 77.571167 \\
\hline 10. & Pieris deota & Ladakh & 34.152588 & 77.577049 \\
\hline 11. & Pieris canidia canis & Coonoor, T.N. & 11.350208 & 76.796104 \\
\hline 12. & Pieris canidia canis & Chennai, T.N. & 13.067439 & 80.237617 \\
\hline 13. & Pieris canidia canis & Thenmala, Kerala & 8.523953 & 76.960924 \\
\hline 14. & Pieris canidia canis & Periyar, Kerala & 9.6031 & 77.1615 \\
\hline 15. & Pieris canidia canis & Munnar, Kerala & 10.089167 & 77.059723 \\
\hline 16. & Pieris canidia canis & Kotagiri, T.N. & 11.4218 & 76.8617 \\
\hline 17. & Pieris canidia indica & Kullu, H.P. & 31.957851 & 77.109459 \\
\hline 18. & Pieris canidia indica & Sikkim & 27.338936 & 88.606506 \\
\hline 19. & Pieris canidia indica & Thenzawl, Mizoram & 23.2808 & 92.7741 \\
\hline 20. & Pieris canidia indica & Lunglei, Mizoram & 22.867069 & 92.765533 \\
\hline 21. & Pieris canidia indica & Lawngtlai, Mizoram & 22.528445 & 92.892634 \\
\hline 22. & Pieris canidia indica & Reiek, Mizoram & 23.6777 & 92.6037 \\
\hline 23. & Pieris canidia indica & Siaha, Mizoram & 22.489735 & 92.979271 \\
\hline 24. & Pieris canidia indica & Goorais Valley, Kashmir & & \\
\hline 25. & Pieris rapae & Goalpara, Assam & 26.17 & 90.620003 \\
\hline 26. & Pieris rapae & Ladakh & 34.152588 & 77.577049 \\
\hline 27. & Pieris rapae & Kargil, Ladakh & 34.5539 & 76.1349 \\
\hline 28. & Pieris rapae & Leh, Ladakh & 34.152588 & 77.577049 \\
\hline 29. & Pieris rapae & Dumka, Ladakh & & \\
\hline 30. & Pieris rapae & Nyoma, Ladakh & 33.2059 & 78.6484 \\
\hline 31. & Pieris rapae & Bilaspur, H.P. & 31.3407 & 76.6875 \\
\hline 32. & Pieris melete & Lawngtlai, Mizoram & 22.528445 & 92.892634 \\
\hline 33. & Pieris melete & Reiek, Mizoram & 23.6777 & 92.6037 \\
\hline 34. & Pieris melete & Zoltan, Mizoram & 22.911099 & 92.756942 \\
\hline 35. & Pieris melete & Ilwas, Chamba, H.P. & 32.5553 & 76.1265 \\
\hline 36. & Pieris extensa & Kameng, Arunachal Pradesh & 27.361012 & 93.040095 \\
\hline
\end{tabular}

with two long, thin arms; aedeagus stout, rounded, curved, ductus ejaculatorious entering widely dorsad; female genitalia with signum well sclerotized and bilobed.

\section{Key to species:}

1. Forewing dorsal side apex and termen black with smooth inner edge up to vein $\mathrm{Cu}_{2}$; hindwing without marginal border. Valva with distal end concave to form a distally pointed process making the appearance of the apex of valve bifid; aedeagus not arched; suprazone abruptly swollen forming dorsal hump before middle, constricted, then again swollen 
tip blunt.

brassicae

- Forewing dorsal side apex and termen with dentate black border up to vein $\mathrm{Cu}_{2}$; hindwing dorsal side with dentate marginal border. Valva with distal end protrudes to form a short, blunt process; aedeagus short, suprazone with a dorsal hump, tip blunt..............................................

2. Forewing dorsal side apex and termen with black dentate border up to vein $\mathrm{Cu}_{1}$; hindwing dorsal side with black marginal dots. Uncus in dorsal view $Y$ shaped with a pointed tip, arms broad.

canidia

-Forewing dorsal side apex with black border; hindwing dorsal side without black marginal dots. Uncus in dorsal view Y-shaped with blunt tip, arms narrow.

rapae

3. Forewing ventral side with a black spot in area $\mathrm{Cu}_{2}$; ventral side of hindwing base and forewing apex light lemon yellow. Valva broader than longer; aedeagus with arched suprazone.

melete

iv). Forewing ventral side without a black spot in area $\mathrm{Cu}_{2}$; ventral side of hindwing and forewing apex dark yellow. Valva broad and long; aedeagus with tortuous suprazone. extensa

Pieris brassicae (Linnaeus, 1758)

Common name: Large Cabbage White (PLATES-I \& II)

Papilio brassicae Linnaeus, 1758; Syst. Nat. (Edn 10) 1: 467.

Pontia chariclea Stephens, 1827; III. Br. Ent. 1 (1): 17.

Pieris brassicae Rober, 1896; Ent. Nachr. 22 (6): 81. Pieris brassicae Krulikovsky, 1902; Revue Russe Ent. 2 (4): 221.

Pieris brassicae Rober, 1907; Gross-Schmett. Erde 1: 45.

Adult (Male): Forewing dorsal surface creamishwhite; base with dusted black scales; costa black; apex and termen widely black up to vein $\mathrm{Cu}_{1}$ with smoothly curved inner edge. Ventral surface white; costa and base little dusted with black scales; apex ochraceous-yellow; black quadrate spots in areas $\mathrm{Cu}_{2}$ and $\mathrm{M}_{3}$. Hindwing dorsal surface creamish-white; a little dusting of black scales at the base; large black spot at the costa. Ventral surface ochraceousyellow, little dusted with black scales; costal spot shows through.

Adult (Female): Forewing dorsal surface creamishwhite; base heavily dusted with blackish scales; apex and termen black; inner margin of the black area not smoothly curved; two black quadrate spots in areas $\mathrm{Cu}_{2}$ and $\mathrm{M}_{3}$. Ventral surface white; costa and base dusted with blackish scales; apex and termen ochraceous-yellow; two quadrate black scales in areas
$\mathrm{Cu}_{2}$ and $\mathrm{M}_{3}$. Hindwing dorsal surface creamish-white with little yellow tinge; black costal spot. Ventral surface ochraceous-yellow with black costal spot visible through.

Wing-span: $60-75 \mathrm{~mm}$.

Male genitalia: Uncus in lateral view narrow, slightly curved, in dorsal view V-shaped; tegumen narrow, sclerotized, V-shaped from dorsal view, uncus and tegumen projected upwardly, latero-ventral projections of tegumen narrow; vinculum sinuous; saccus sclerotized, curved upwardly; appendices angulares long, well sclerotized, broad towards valva, gradually narrow towards tegumen; juxta conical, arms sinuous; valva long, tortuous, broad, sparsely setosed, distal end concave to form a distally pointed process
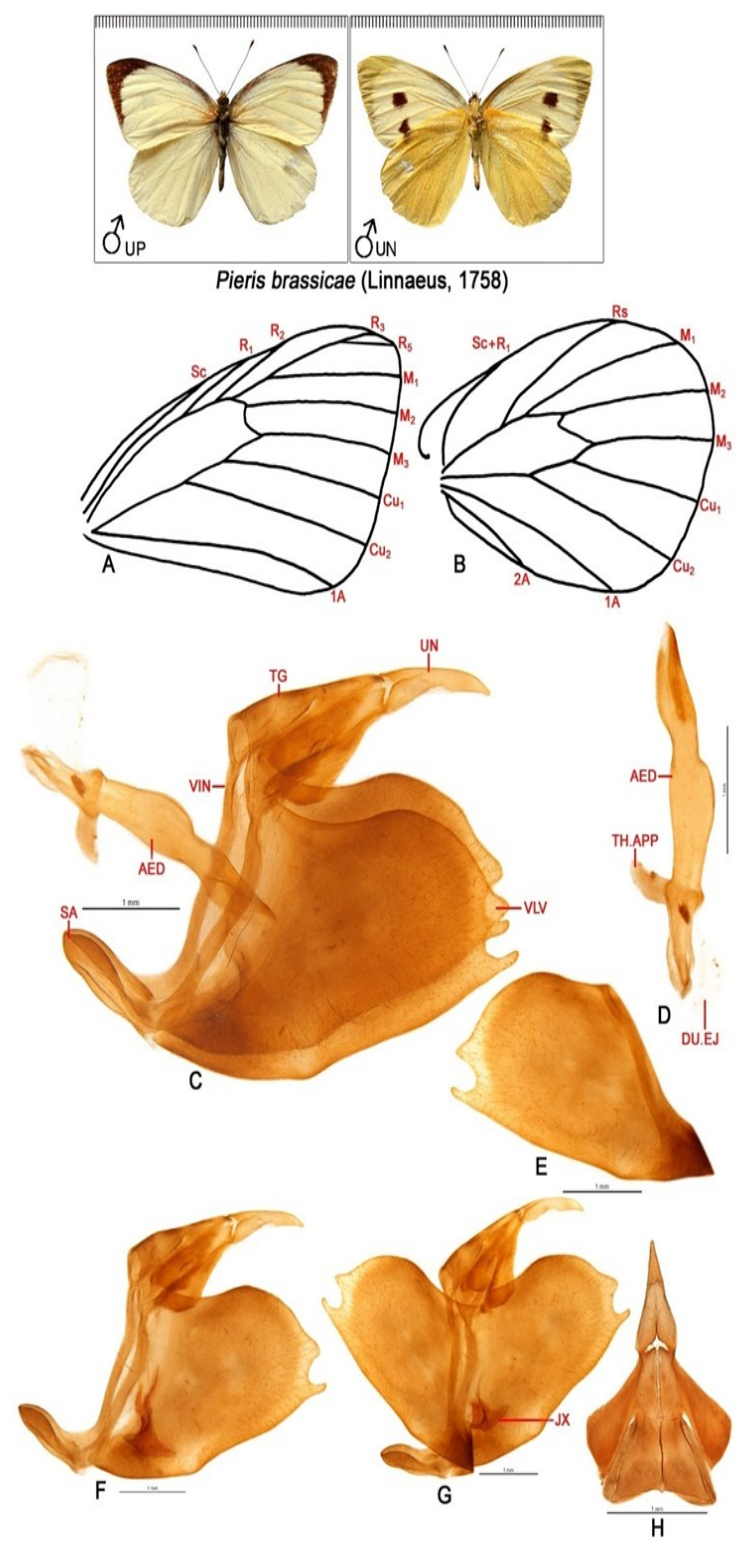

PLATE-I. Pieris brassicae (male). A. Forewing, B. Hindwing, C.\&F. Male genitalia, (lateral view), D. Aedeagus, E. Valva, G. Male genitalia (after opening), H. Uncus (Dorsal view). 

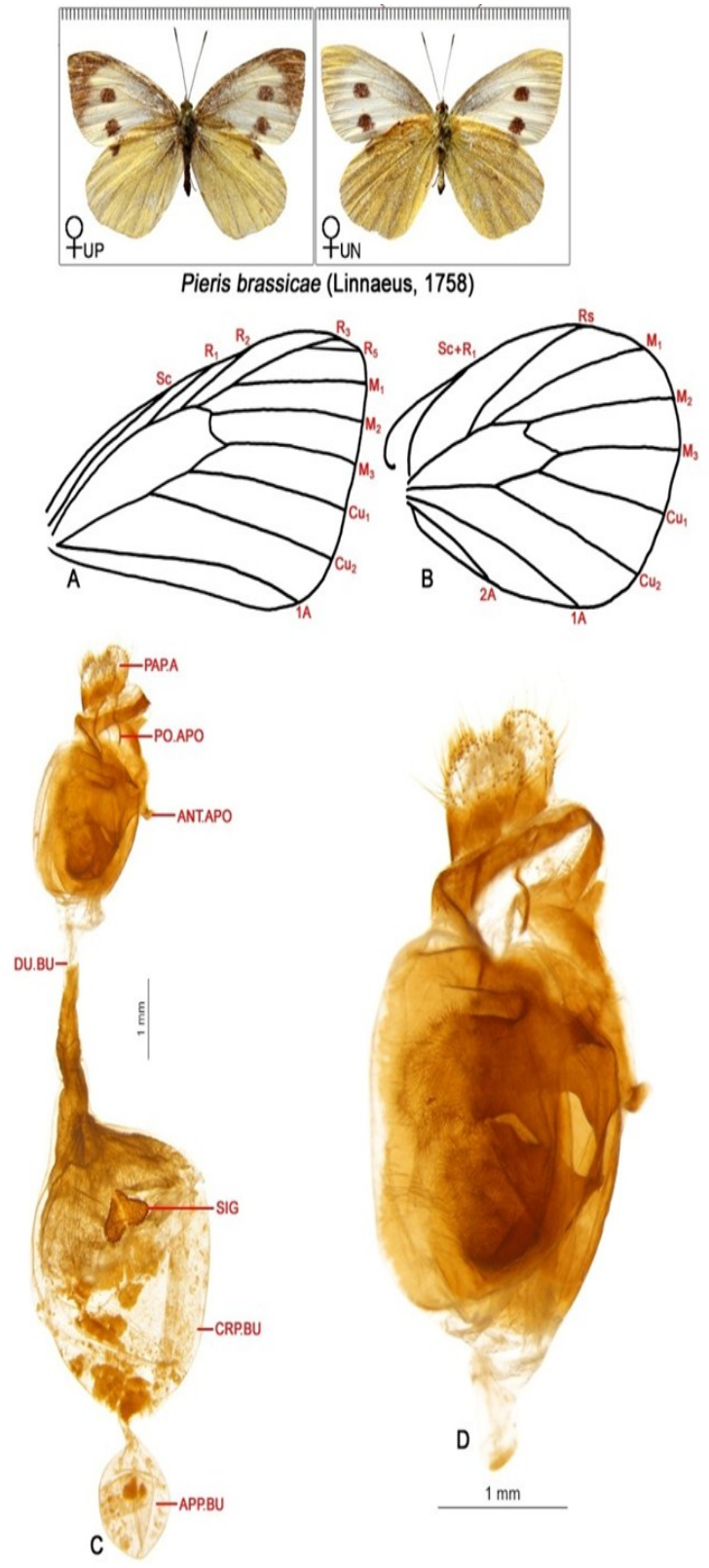

PLATE-II. Pieris brassicae (female). A. Forewing, B. Hindwing, C. Female Genitalia, D. Papilla analis.

making the appearance of the apex of valve bifid; aedeagus short, subzone smaller than suprazone, latter abruptly swollen forming dorsal hump before middle, constricted, then again swollen, tip blunt, thecal appendage ventral, moderately broad, ductus ejaculatorious enters dorsally.

Female genitalia: Corpus bursae rounded, gradually narrow towards appendix bursae; signum bifid by shallow suture, outer margins more sclerotized; appendix bursae globular, moderately large, membranuous, clearly separated from corpus bursae; ductus bursae long, well sclerotized; papilla analis rounded and setosed; posterior apophysis long, thin, sclerotized, blunt tips; anterior apophysis smaller, broad.
Material examined: ZSI, Kolkata, National Museum Collections:1ð, 12.iv.1916, Sukha, Nainital, Uttarakhand; 1, 23.vi.1959, Shillong, Meghalaya. 3ึ̄, 19.iv.2016, Punjabi University, Patiala, Punjab, (Coll. Manpreet Kaur); 3ð, 2+, 14.vi.2016, Thalyara, (Coll. Manpreet Kaur); 6§, 3ㅇ, 6.iv.2017, Thenzawl, Mizoram, (Coll. Manpreet Kaur); 4ð, 2ᄋ, 10.iv.2017, Lunglei, Mizoram, (Coll. Manpreet Kaur); 2ภ, 3ㅇ, 14.iv.2017, Lawngtlai, (Coll. Manpreet Kaur); 2え, 18.iv.2017, Champai, Mizoram, (Coll. Manpreet Kaur); 2ð̂, 19.iv.2017, Reiek, Mizoram, (Coll. Manpreet Kaur); 3今, 2ᄋ,3.iii.2018, Taradevi, Himachal Pradesh, (Coll. Manpreet Kaur).

Distribution India: Sikkim, Uttarakhand, Himachal Pradesh, Nagaland, Jammu and Kashmir, Manipur, Arunachal Pradesh, Meghalaya, Punjab, Delhi, Uttar Pradesh.

Elsewhere: Nepal, West Siberia, South Siberia, Mongolia, China, Japan, Amur, Ussuri, Thailand, Vietnam, Yunnan, Cyprus.

Remarks: Pieris brassicae (Linnaeus) is a common species distributed in the Oriental and Palearctic regions. Bingham (1907), Antram (1924) and Talbot (1939) described the male and female external characters and distribution of this concerned species. Verity (1919) studied the seasonal variations in $P$. brassicae by compairing the features of three broods of this species and concluded that the third brood possesses intermediate features between first brood and second brood. In this present work, the morphological characters and genitalic characters of both the sexes have been described and compared with other Indian species of the genus. The genitalia is also compared with the illustrations given by Klots (1931). Its valve, aedeagus and uncus show remarkable differences from other species of the genus. The valve is long, tortuous, slightly concave at the base of costa. The distal tip invaginates to form a smaller, narrow and blunt ended process. These processes are absent in other Indian species of this genus. Aedeagus with proximal part of suprazone abruptly swollen forming dorsal hump. Saccus is longer as compared to other species of this group. In females, the signum is inverted heart-shaped in $P$. brassicae.

Pieris deota (de Niceville, 1884)

Common name: Dusky White (PLATE-III)

Mancipium deota de Niceville, 1884; J. Asiat. Soc. Bengal 52: 82.

Pieris roborowskii Alpheraky, 1887; Mem. Lep. 3: 404.

Pieris roborowskii Grum- Grshimailo, 1890; Mem. Lep. 3: 214.

Pieris deota Korb \& Bolshakov, 2011; Eversmannia Suppl. 2:26. 

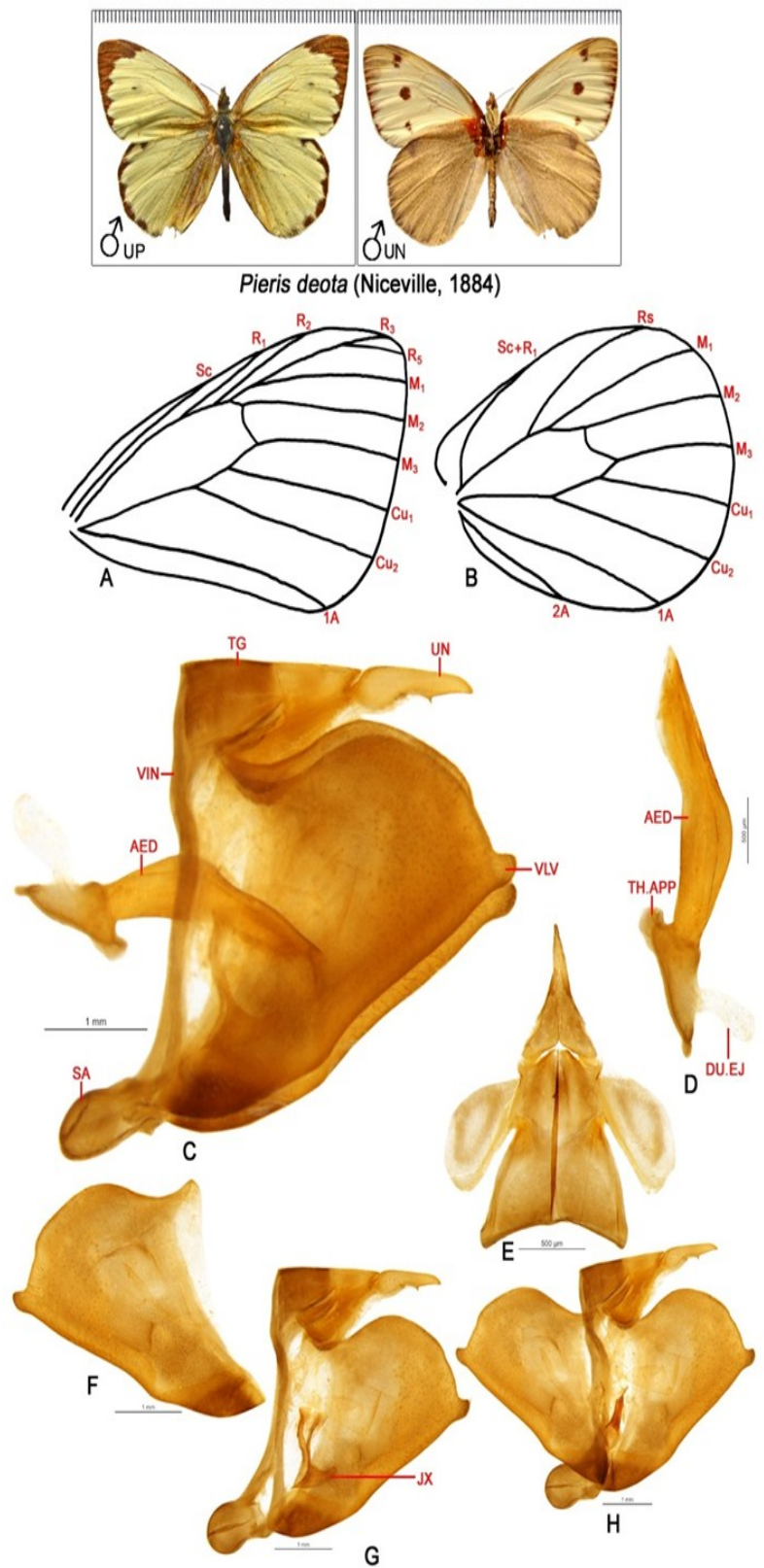

PLATE-III. Pieris deota (male). A. Forewing, B. Hindwing, C.\&G. Male Genitalia, (lateral view), D. Aedeagus, E. Uncus (Dorsal view), F. Valva, H. Male genitalia (after opening).

Adult (Male): Forewing dorsal surface creamishwhite; costa thin black; apex and termen black with denticulate inner margin; black thin spot in area $M_{3}$. Ventral surface white with light brownish apex and termen; dark brownish spots in areas $\mathrm{Cu}_{2}, \mathrm{M}_{3}$ and $R_{5}$. Hindwing white with base and inner margin dusted with black scales; outer margin with denticulate black border. Ventral surface light brownish little dusted with black scales; black dot in the subcostal area.

Wing-Span: 56-65 mm.

Male genitalia: Uncus narrow, straight, blunt tip, in dorsal view V-shaped, shorter and narrower than tegumen; tegumen sclerotized, anteriorly broad; vin- culum slightly curved, sclerotized, saccus short, flattened, distal end strongly rounded; juxta large, upper part with long, slender, curved arms, lower part forms conical structure caudad; valva obliquely oriented, costa strongly convex, distal end protrudes to form a short, blunt process; aedeagus short, robust, subzone smaller than suprazone, suprazone with dorsal hump, blunt apically, thecal appendage short, distal end blunt, ductus ejaculatorious enters dorsally.

Material examined: ZSI, Kolkata, National Museum Collections.

1ठ, 4.vii.1887, 1, viii.1914, Ladakh.

Distribution India: Kashmir

Elsewhere: Hunza, Baluchistan, Pakistan.

Remarks: Pieris deota (de Niceville) is protected under Schedule II of the Indian Wildlife (Protection) Act, 1972. It is distributed between the altitude of $3600 \mathrm{~m}$ to $4400 \mathrm{~m}$ and has been recorded from India, Central Asia, Pakistan and Tibet. Bingham (1907), Antram (1924) and Talbot (1939) compared the morphological attributes of $P$. deota with $P$. brassicae and reported them as closely resembling species. In the present work, the morphological as well as genitalic attributes of $P$. deota have been studied and illustrated for the first time, and compared with P.brassicae \& other Indian species of this group. It has been observed that both the species are morphologically somewhat similar with slight differences. Both the species are white dorsally with a black border on the dorsal side of forewing apex and termen and on the ventral surface of forewing with a black spot in areas $\mathrm{M}_{3}$ and $\mathrm{Cu}_{2}$. In Pieris deota, the black border on dorsal side of forewing apex and termen and on the dorsal side of hindwing margin is macular whereas in $P$. brassicae, the black margin on the dorsal side of forewing apex and termen is smooth and on the dorsal side of hindwing this border is absent. The black spots in areas $\mathrm{M}_{3}$ and $\mathrm{Cu}_{2}$ are large in Pieris deota with additional submarginal spot whereas these spots are small in P.brassicae. In $P$. deota, the valva is obliquely oriented with costal margin strongly convex, and the distal end protrudes to form a small, blunt ended process. The aedeagus is highly robust with dorsal margin strongly convex and ventral margin almost linear. In $P$. brassicae, the valve is long, tortuous, slightly concave at the base of costa, and the distal tip invaginates to form a smaller, narrow and blunt ended process. Aedeagus with proximal part of suprazone abruptly swollen forming dorsal hump.

Pieris canidia (Linnaeus, 1768)

Common name: Indian Cabbage White (PLATES-IV to VIII)

Papilio canidia Linnaeus, 1768; Amoenitates Acad. 7: 504. 

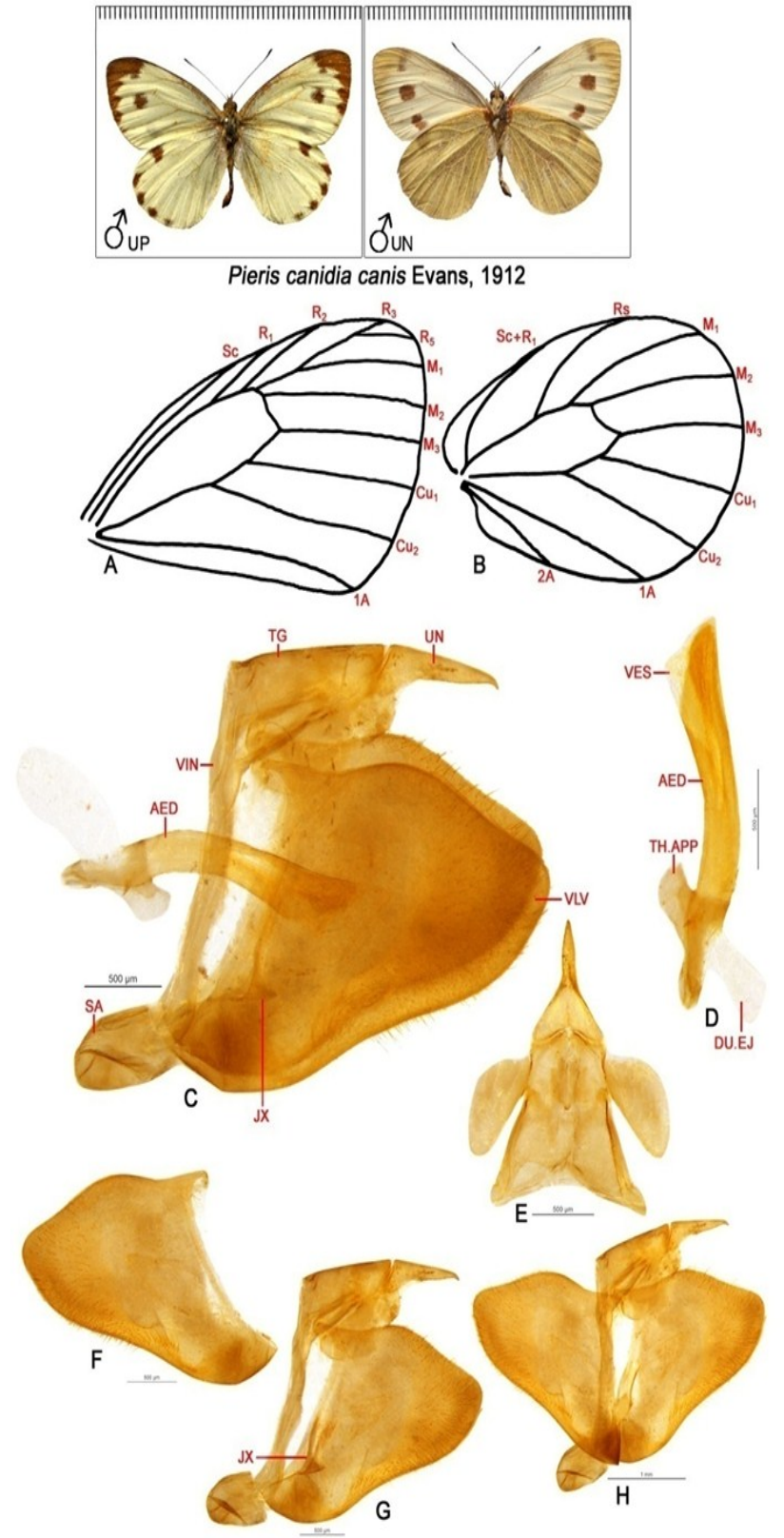

PLATE-IV. Pieris canidia canis (male). A. Forewing, B. Hindwing, C.\&G. Male Genitalia (lateral view), D. Aedeagus, E. Uncus (Dorsal view), F. Valva, H. Male genitalia (after opening) .

Papilio gliciria Cramer, 1777; Uitl. Kapellen 2: 115. Pieris canidia Korb \& Bolshakov, 2011; Eversmannia Suppl. 2: 27.

Diagnosis: Forewing dorsal side apex black; termen with black denticulate margin upto vein $\mathrm{Cu}_{1}$; a black spot in area $\mathrm{M}_{3}$. Ventral side with black spots in areas $\mathrm{M}_{3}$ and $\mathrm{Cu}_{2}$. Hindwing dorsal side with a black costal spot in area Rs.

Male genitalia: Uncus narrow, slightly sinuous, distal tip pointed and downcurved, in dorsal view $Y$ shaped; tegumen slightly broad, somewhat rectangular in dorsal view, longer than uncus; vinculum thin, heavily sclerotized, ; saccus broad, distal end

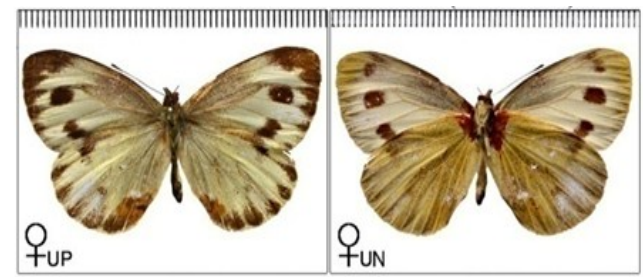

Pieris canidia canis Evans, 1912
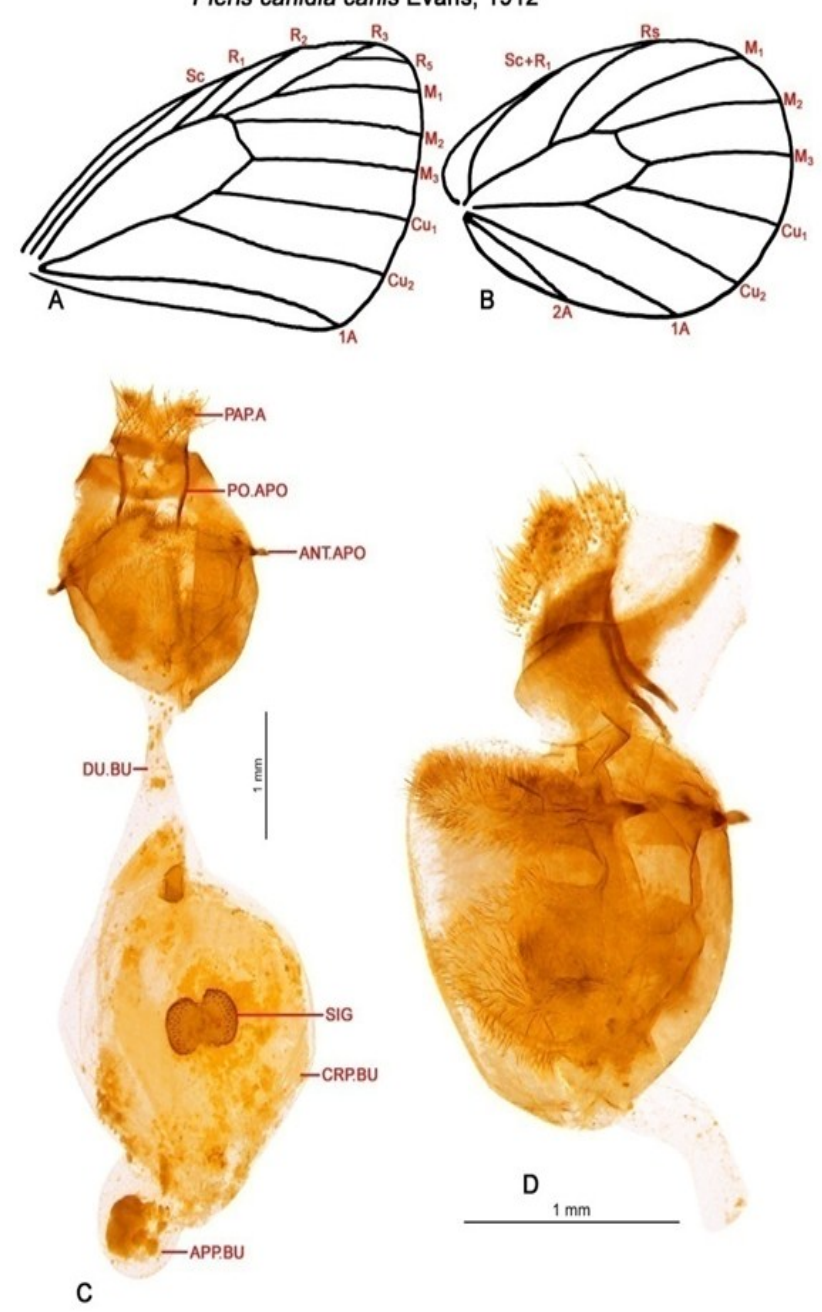

PLATE-V. Pieris canidia canis (female). A. Forewing, B. Hindwing, C. Female Genitalia, D. Papilla analis.

rounded; juxta reduced cone-shaped with thin, sclerotized, long arms; valva broad proximally, marginal areas sclerotized and setosed, apex narrow and blunt; costa and lateral margin sinuous; aedeagus robust, slightly curved, subzone smaller and sclerotized than suprazone, thecal appendage ventral, moderately broad, ductus ejaculatorious enters dorsally.

Female Genitalia: Corpus bursae spherical, large; signum double, broad, outer margins more sclerotized, spinuous and invaginated in the center; appendix bursae oval, membranuous; ductus bursae robust; papilla analis sclerotized and setosed; posterior 

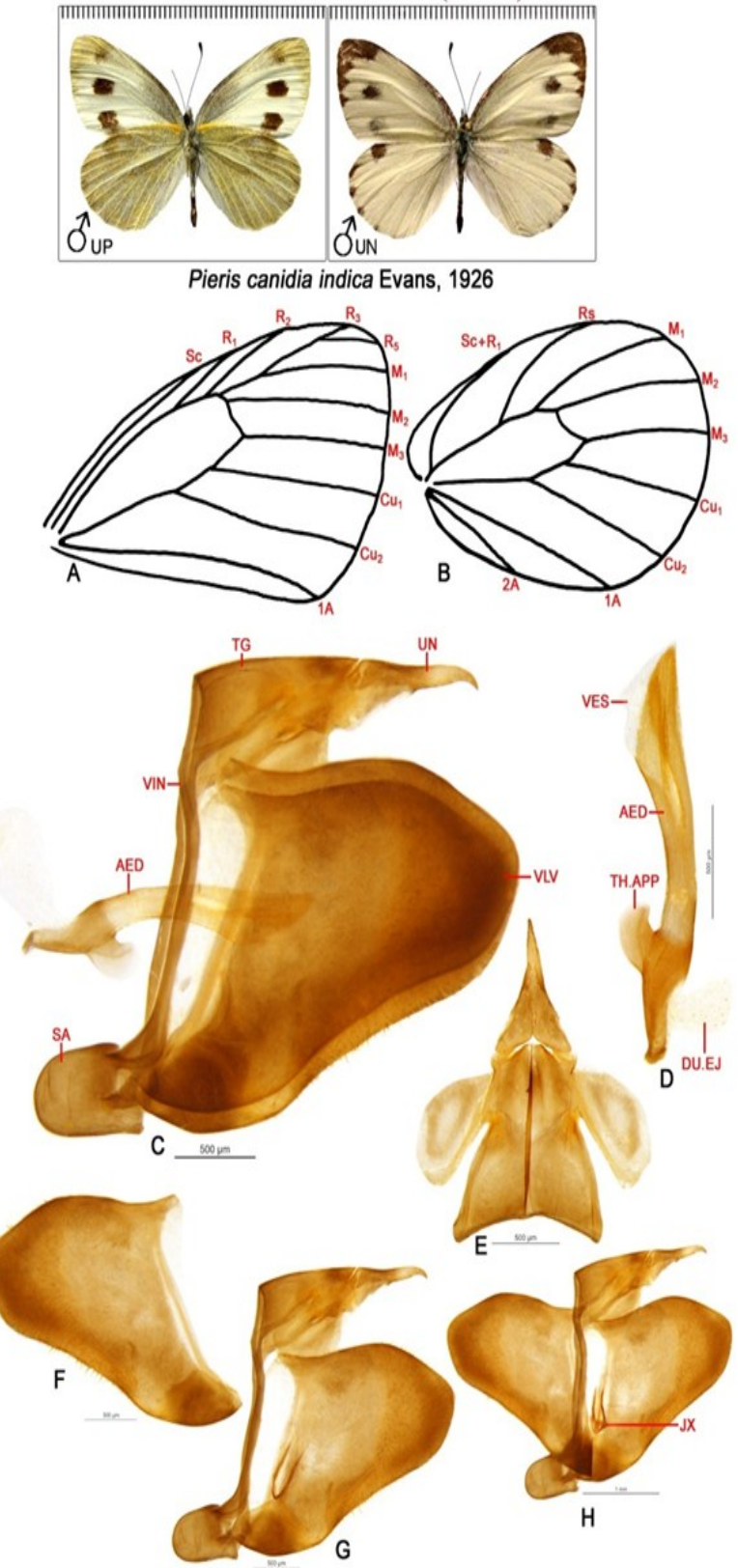

PLATE-VI. Pieris canidia indica (male). A. Forewing, B. Hindwing, C.\&G. Male Genitalia (lateral view), D. Aedeagus, E. Uncus (Dorsal view), F. Valva, H. Male genitalia (after opening).

apophysis long, thin, curved, sclerotized, blunt tips; anterior apophysis smaller, blunt tips.

Remarks: Pieris canidia (Linnaeus) is a common species widely distributed throughout India at the altitude of $600 \mathrm{~m}$ to $3400 \mathrm{~m}$. There are two subspecies, i.e. P. c. canis Evans from South India, North Maharashtra, Madhya Pradesh and Chhattishgarh and $P$. c. indica Evans from Arunachal Pradesh, Mizoram, Manipur, Sikkim, Jammu and Kashmir, Delhi, Punjab and Uttar Pradesh. In the present work, the morphological characters, genitalic attributes and distribution of both the subspecies have
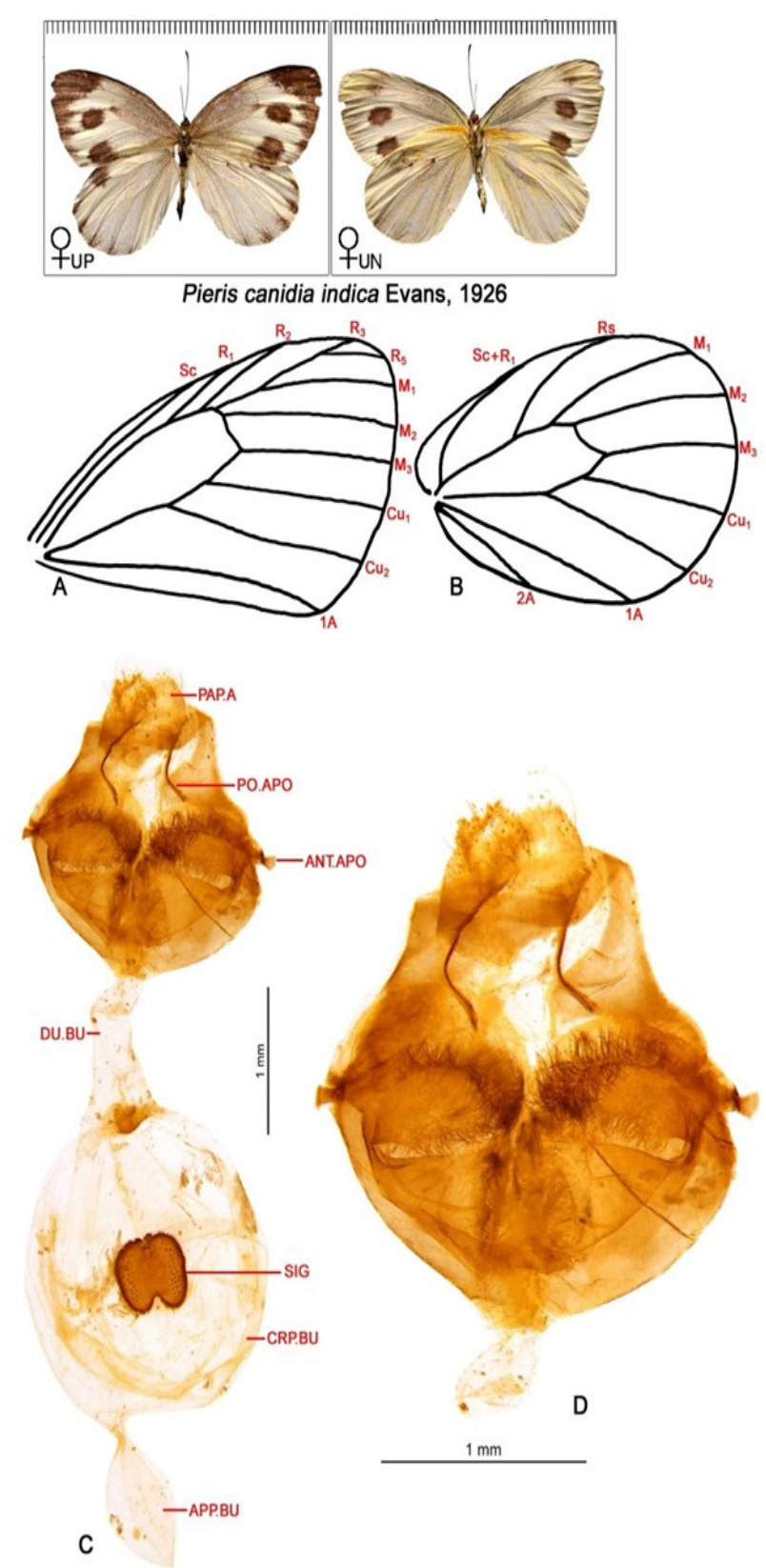

PLATE-VII. Pieris canidia indica (female). A. Forewing, B. Hindwing, C. Female Genitalia, D. Papilla analis.

been studied, illustrated and compared. The genitalic attributes of $P$. canidia have been also compared with $P$. rapae. In $P$. canidia, the uncus is prominently $Y$-shaped from dorsal view with pointed tip whereas in $P$. rapae, the uncus is with a blunt tip. In $P$. canidia, the valve is sinuous with the slightly narrowly rounded and tortuous distal end as compared to $P$. rapae and another species of the genus. In females, the signum is somewhat bilobed in case of canidia whereas in case of $P$. rapae the signum is almost rounded with well-sclerotized boundaries. 

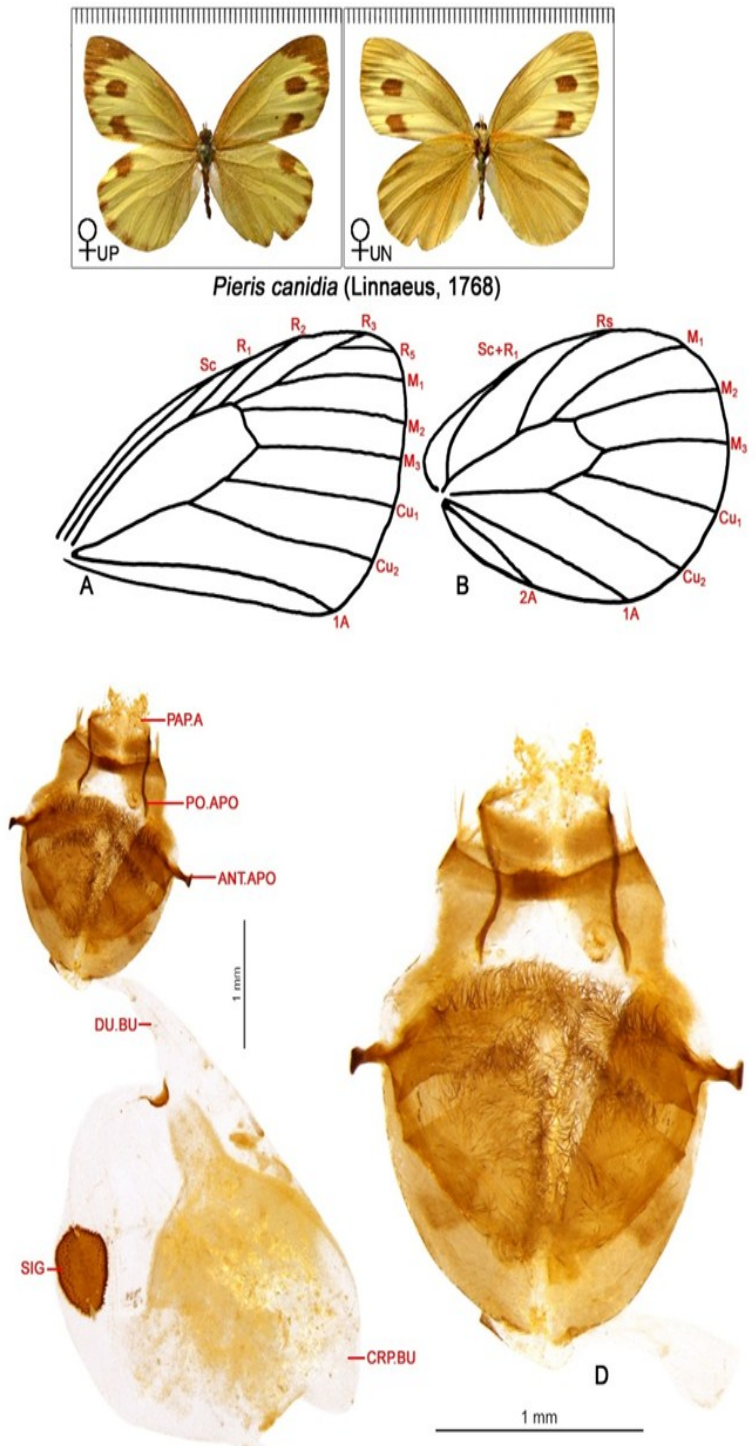

C

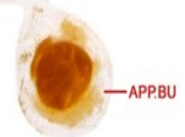

PLATE-VIII. Pieris canidia indica (female, yellow form). A. Forewing, B. Hindwing, C. Female Genitalia, D. Papilla analis.

\section{Key to subspecies:}

1. Markings dark; forewing dorsal side with small spur produced in area $\mathrm{R}_{5}$ from black apical portion.

canidia canis

5. Markings less dark; forewing dorsal side without spur from black apical portion

canidia indica

\section{Pieris canidia canis Evans, 1912}

\section{Common name: Sahyadri Cabbage White}

Pieris canidia canis Evans, 1912; J. Bombay nat. Hist. Soc. 21 (2): 559.

Adult (Male): Wing maculation dark; forewing dorsal side with apex and termen black with small spur produced in area $R_{5}$ from black apical portion; ventral surface white with lemon-yellowish apex.

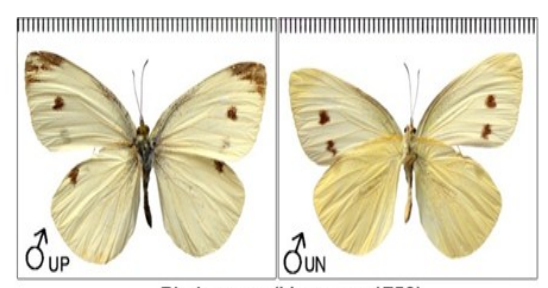

Pieris rapae (Linnaeus, 1758)

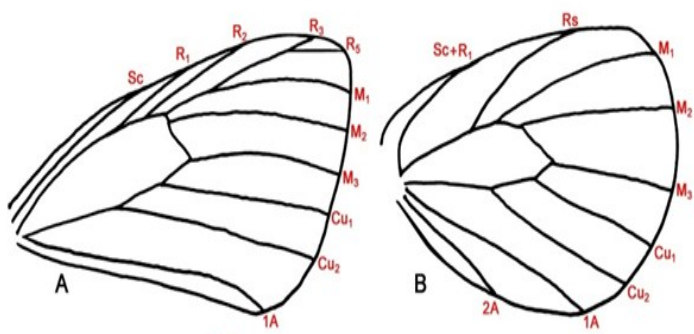

TG
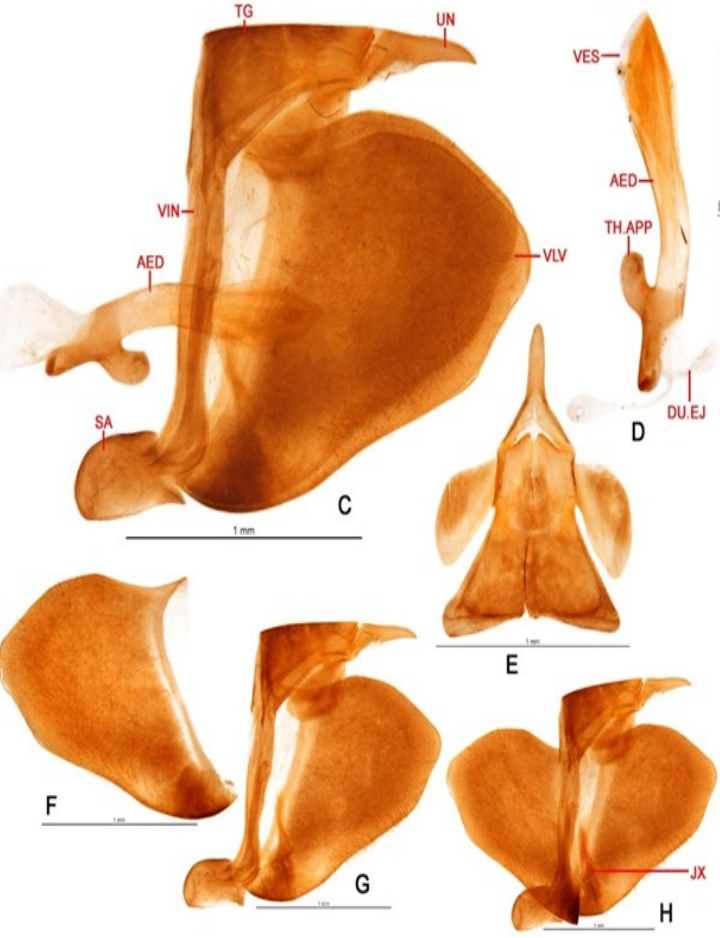

PLATE-IX. Pieris rapae (male). A. Forewing, B. Hindwing, C.\&G. Male Genitalia (lateral view), D. Aedeagus, E. Uncus (Dorsal view), F. Valva, H. Male genitalia (after opening) .

Hindwing with slightly large black marginal spots; ventral side ochraceous-brownish.

Adult (Female): Wing maculation same as in male but extremely dark and broad. The base of dorsal surface of both the wings and base of ventral surface of forewing dusted with blackish scales.

Wing-Span: 45-60 mm.

Male genitalia: Uncus inclined distally, distal tip pointed and downcurved, in dorsal view Y-shaped; tegumen slightly broad, somewhat rectangular in dorsal view, longer than uncus; vinculum broad; saccus broad, distal end rounded; juxta reduced coneshaped with thin, long, broad and flattened arms; valva broad proximally, marginal area setosed, apex 

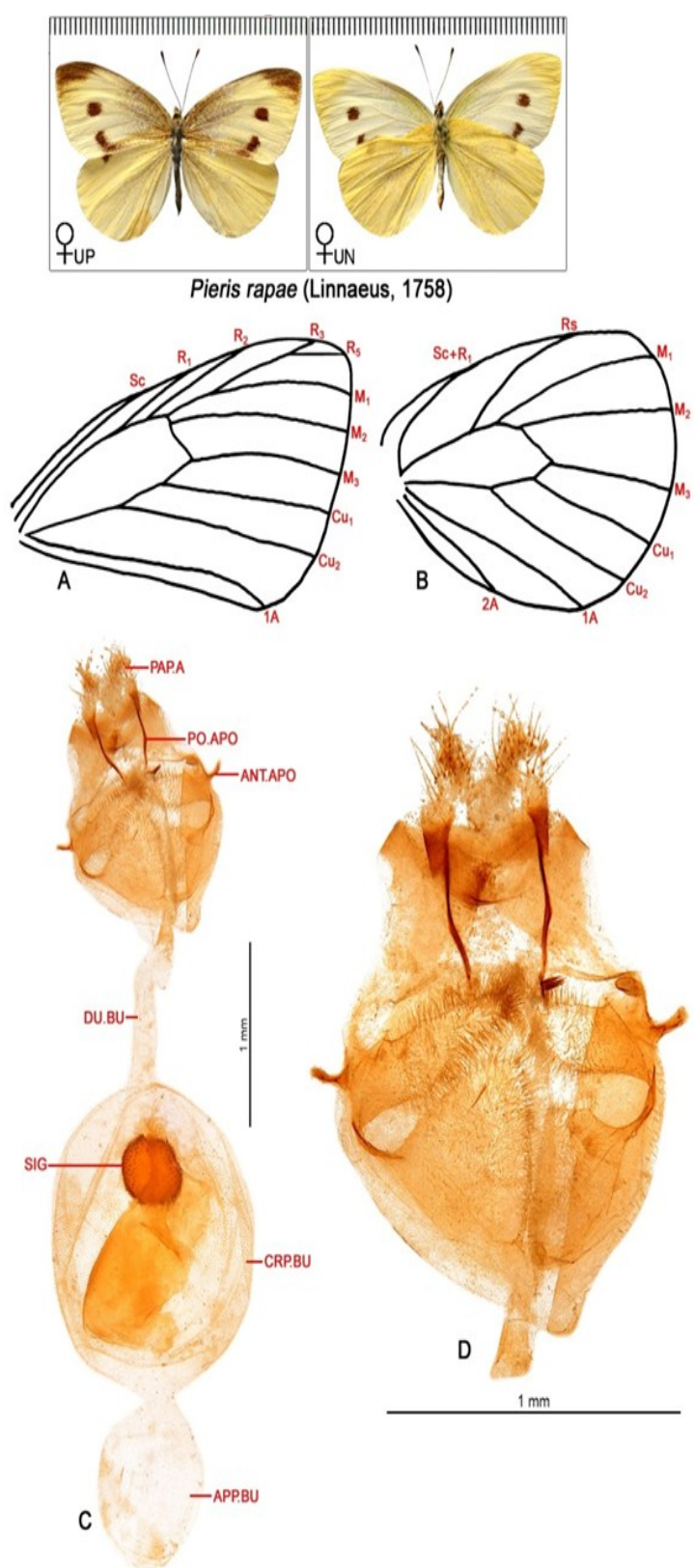

PLATE-X. Pieris rapae (female). A. Forewing, $B$. Hindwing, C. Female Genitalia, D. Papilla analis.

narrow and blunt; costa and lateral margin sinuous; aedeagus robust, slightly curved, subzone smaller than suprazone, thecal appendage ventral, moderately broad, ductus ejaculatorious enters dorsally.

Female genitalia: Corpus bursae somewhat spherical, gradually narrow towards ductus bursae; signum broad, outer margins more sclerotized, spinuous and invaginated in the center; appendix bursae oval, membranuous; ductus bursae small; papilla analis sclerotized and setosed; posterior apophysis long, thin, sclerotized, blunt tips; anterior apophysis smaller, blunt tips, genital plate bilobed, each lobe oval shaped, densely hairy.

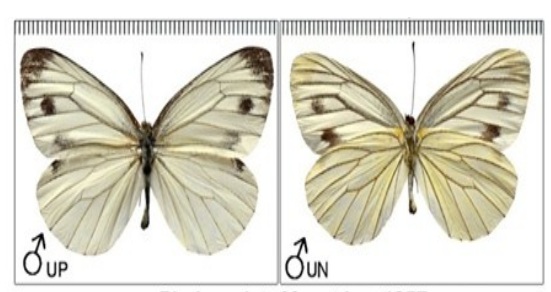

Pieris melete Menetries, 1857
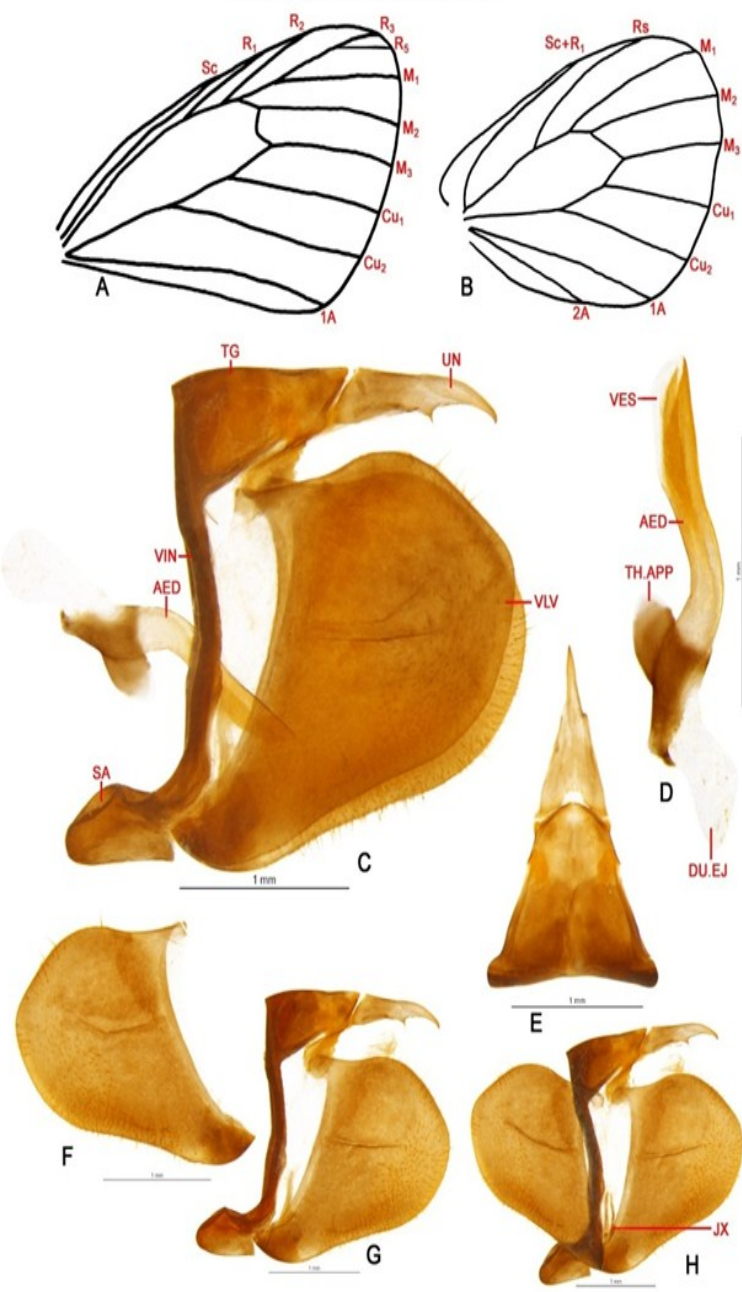

PLATE-XI. Pieris melete (male, WSF). A. Forewing, $B$. Hindwing, C.\&G. Male Genitalia (lateral view), D. Aedeagus, E. Uncus (Dorsal view), F. Valva, H. Male genitalia (after opening).

Material examined: ZSI, Kolkata, National Museum Collections.

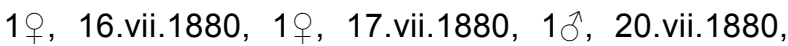

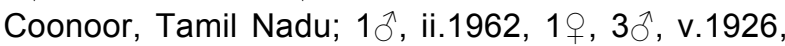

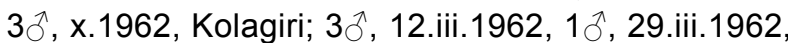
1§., 31.iii.1962, Madras, Tamil Nadu, (Coll. K.V.L Narayana); 4ð, 7.viii.2017, Thenmala, Kerala, (Coll. Manpreet Kaur); 2へ, 3, 12.viii.2017, Periyar, Kerala, (Coll. Manpreet Kaur); 2へ, 14,.viii.2017, Munnar, Kerala, (Coll. Manpreet Kaur).

Distributin India: South India, North Maharashtra, Madhya Pradesh, Chhattishgarh.

Elsewhere:- 

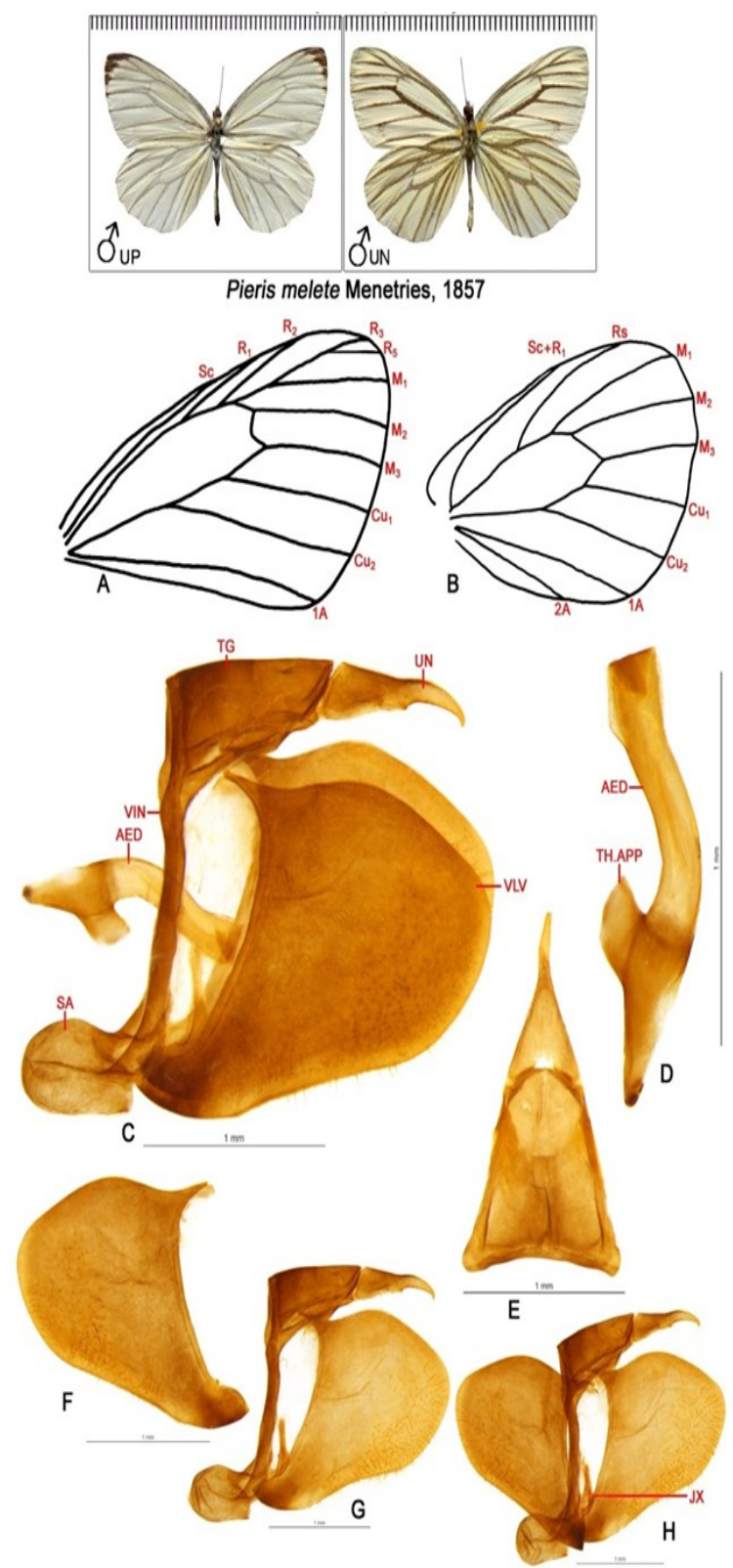

PLATE-XII. Pieris melete (male, DSF). A. Forewing, $B$. Hindwing, C.\&G. Male Genitalia (lateral view), D. Aedeagus, E. Uncus (Dorsal view), F. Valva, H. Male genitalia (after opening).

Remarks: $P$. canidia canis is a common species distributed in South India. Evans (1927) recorded $P$. canidia canis as very common from Travancore to Nilgiris. Evans (1932) devised a key for this subspecies on the basis of their morphology including its distribution. Talbot (1939) reported $P$. canidia canis as common subspecies in Nilgiri hills and compared its external morphology subspecies $P$. canidia indica. Gasse (2013) and Varshney Smetacek (2015) recorded its distributional range. In this present research work, the morphological characters, genitalic attributes and distribution of $P$. canidia canis have
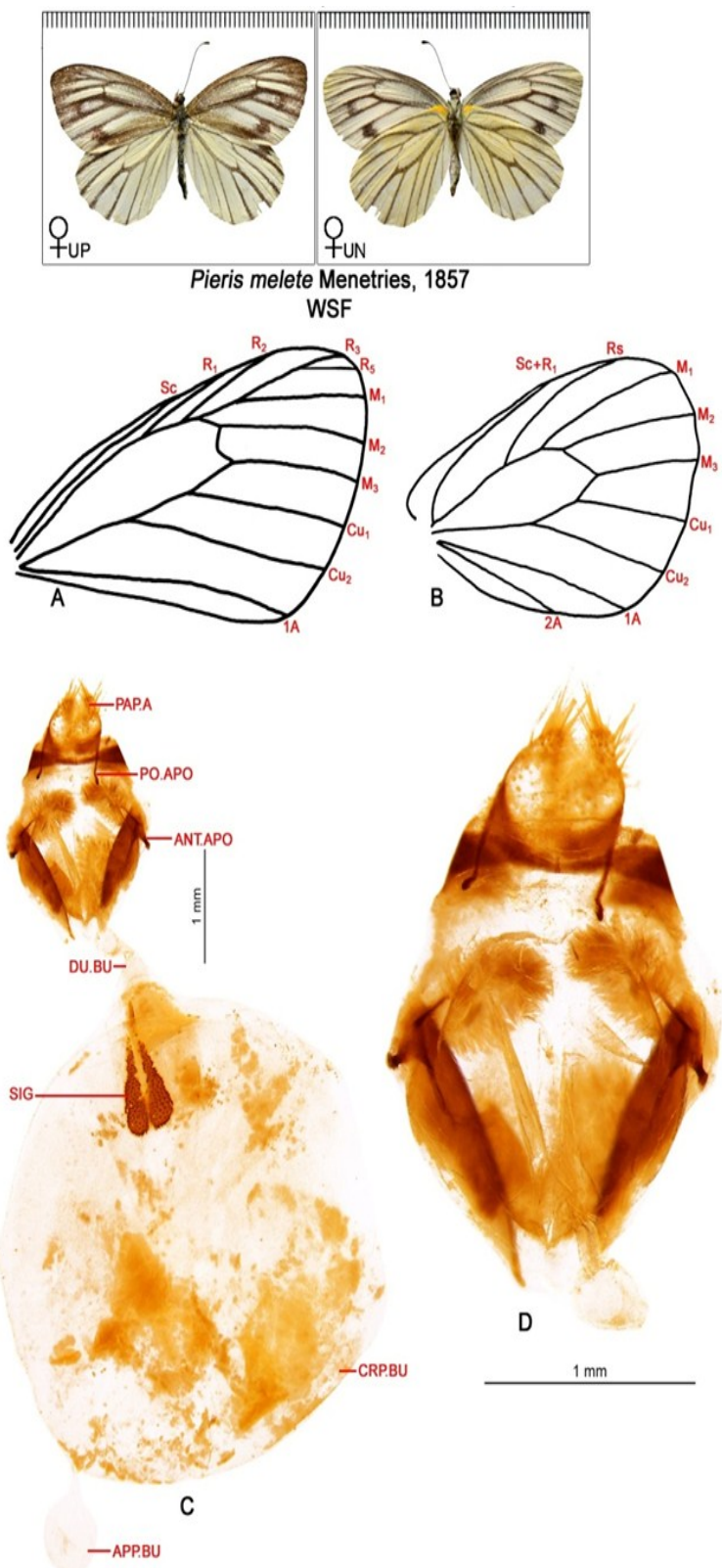

PLATE-XIII. Pieris melete (female, WSF). A. Forewing, B. Hindwing, C. Female Genitalia, D. Papilla analis.

been studied and illustrated. The valve of $P$. canidia canis is more sinuous and with the slightly narrowly rounded distal end as compared to other Indian species of the genus.

Pieris canidia indica Evans, 1926

Common name: Himalayan Cabbage White

Pieris canidia indica Evans, 1926; J. Bombay nat. Hist. Soc. 31 (3): 712.

Adult (Male): All the markings similar to Pieris canidia canis but little smaller and less heavily dark in Pieris canidia indica. The small spur produced in area $R_{5}$ from the black apical portion absent, the black 


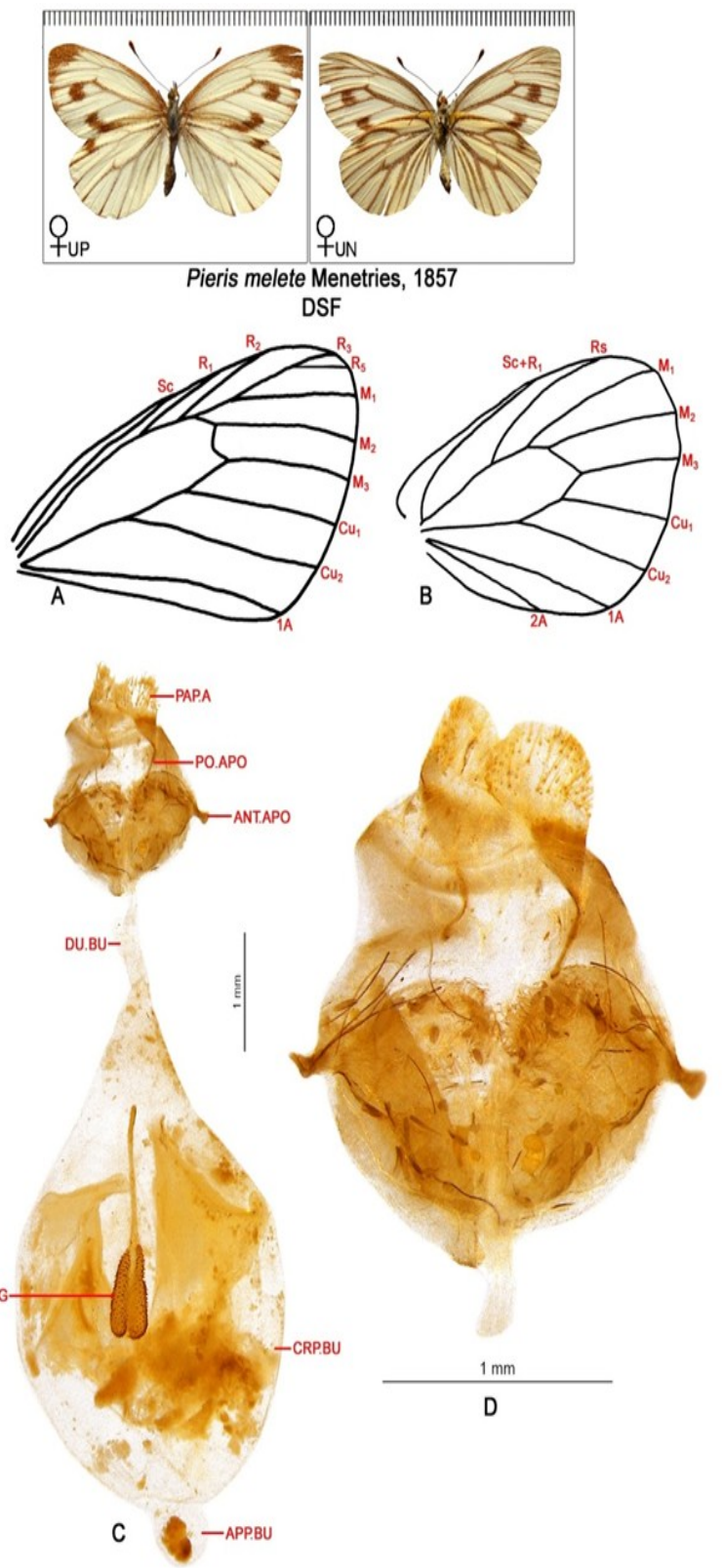

PLATE-XIV. Pieris melete (female, DSF). A. Forewing, B. Hindwing, C. Female Genitalia, D. Papilla analis.

marginal spots are smaller and forewing ventral side apex and hindwing ventral side yellowish-green in Pieris canidia indica.

Adult (Female): Markings similar to as in male but slightly dark and broad. Forewing ventral side apex and hindwing ventral side light yellowish-green.

Wing-Span: 45-60 mm.

Male genitalia: Similar to as in $P$. canidia canis with slight difference in the uncus. The uncus is almost straight with the dorsal margin of the uncus slightly concave and distal tip arched and downcurved in case of $P$. canidia indica.

Female Genitalia: Similar to as in $P$. canidia canis.

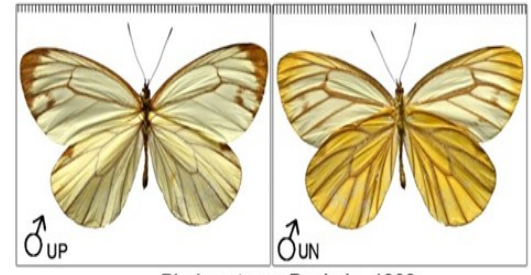

Pieris extensa Poujade, 1888
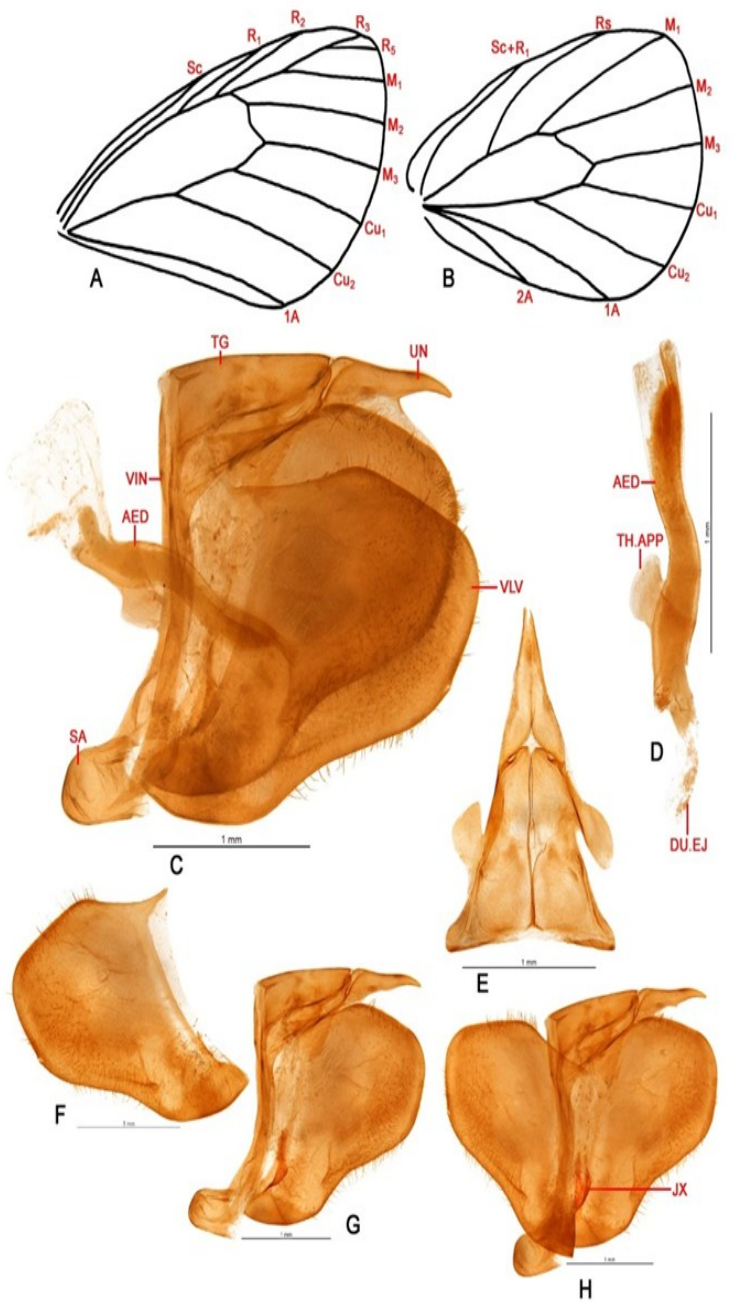

PLATE-XV. Pieris extensa (male). A. Forewing, B. Hindwing, C.\&G. Male Genitalia (lateral view), D. Aedeagus, E. Uncus (Dorsal view), F. Valva, H. Male genitalia (after opening).

Material examined: ZSI, Kolkata, National Museum Collections: $1{ }^{\lambda}, 2$, 9 , 5.iv.1880, Kulu; 1 , 23.vi.1887, Sind valley, Kashmir; 1ð, 23.viii.1887, Goorais valley, Kashmir; 1ठ, vi.1890, Sikkim; 1ð, 6.viii.1959, Sikkim (Coll. A.G.K Manon). 50, 2, 6.iv.2017, Thenzawl, Mizoram, (Coll. Manpreet Kaur); 6 ${ }^{\lambda}, 4$, 10.iv.2017, Lunglei, Mizoram, (Coll. Manpreet Kaur); 5̧, 12.iv.2017, Siaha, Mizoram, (Coll. Manpreet

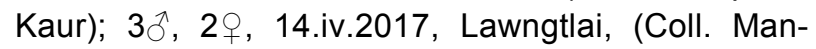
preet Kaur); 4ð, 2†, 19.iv.2017, Reiek, Mizoram, (Coll. Manpreet Kaur).

Distribution India: Arunachal Pradesh, Mizoram, Manipur, Sikkim, Jammu and Kashmir, Delhi, 
Punjab, Uttar Pradesh.

Elsewhere: West China, Burma, Hainan, Taiwan, Singapore, Turkestan, Japan, Yunnan.

Remarks: $P$. canidia indica is a common species distributed in North-East India. Evans (1927) reported $P$. canidia indica as very variable subspecies. Evans (1932) devised a key for this subspecies on the basis of their morphology including its distribution. Talbot (1939) compared its external morphology subspecies P. canidia canis. Gasse (2013) and Varshney and Smetacek (2015) recorded its distributional range. In this present research work, the male and female genitalic attributes of $P$. canidia indica have been compared with $P$. canidia canis for the first time. The genitalia of both the subspecies are similar with a slight difference in their uncus. In $P$. canidia indica, the uncus in lateral perspective is almost straight with the dorsal margin of the uncus slightly concave and distal tip arched and downcurved whereas, in $P$. canidia canis, the uncus is inclined downwardly with distal tip downcurved.

Pieris rapae (Linnaeus, 1758)

Common name: Small Cabbage White (PLATES-IX \& $\mathrm{X})$

Papilio rapae Linnaeus, 1758; Syst. Nat. (Edn 10) 1:468.

Pieris rapae Rolfe, 1876; Entomologist 9:199.

Pieris rapae Krulikovsky, 1890; Bull. Soc. Imp. Nat. Moscou 4 (2): 210.

Pontia rapae Grum-Grshimailo, 1890; Mem. Lep. 4: 218.

Pieris rapae Holloway \& Peters, 1976; J. Nat. Hist. 10: 295.

Pieris rapae Korb \& Bolshakov, 2011, Eversmannia Suppl. 2: 27.

Adult (Male): Smaller in size. Forewing dorsal surface white; costa lightly dusted with blackish scales; apex wide blackish; black circular spot in the centre of area $\mathrm{M}_{3}$. Ventral surface white; costa and anterior half of the cell dusted with blackish scales; moderate blackish spots in areas $\mathrm{M}_{3}$ and $\mathrm{Cu}_{2}$. Hindwing dorsal surface white; subapical black small spot in area Rs. Ventral surface creamish-white without maculation.

Adult (Female): Forewing dorsal surface creamishwhite; base, cell and costa dusted with blackish scales; apex thick brownish-black; moderate dark brownish-black spots in areas $\mathrm{Cu}_{2}$ and $\mathrm{M}_{3}$. Ventral surface white; costa and anterior part of the cell dusted with blackish scales; apex yellowish-white; dark brownish-black spots in areas $\mathrm{Cu}_{2}$ and $\mathrm{M}_{3}$. Hindwing dorsal surface creamish- white with a dark black subapical spot. Ventral surface yellowish-white; little dusted with blackish scales.

Wing-Span: $40-55 \mathrm{~mm}$.

Male Genitalia: Uncus straight, slender, distal point- ed tip, in dorsal view $Y$-shaped; tegumen sclerotized, somewhat triangular in lateral view, longer than uncus; vinculum sclerotized, broad; saccus broad, distal end rounded; appendices angulares broad ; juxta cone-shaped; valva broad, sparsely setosed, distal tip blunt; aedeagus short, broad, subzone smaller than suprazone, thecal appendage ventral, rounded, ductus ejaculatorious enters dorsally.

Female Genitalia: Corpus bursae large, spherical with minute spicules; signum quadrate in shape, outer margin more sclerotized and spinuous; appendix bursae moderately large, membranuous, attached to corpus bursae in close proximity; ductus bursae broad; papilla analis pilosed; posterior apophysis much longer, slender, heavily sclerotized, pointed tips; anterior apophysis small with blunt ends; genital plate bilobed, each lobe hirsuate.

Material examined: ZSI, Kolkata, National Museum Collections.

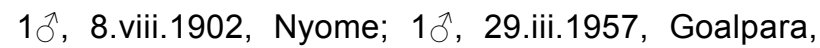

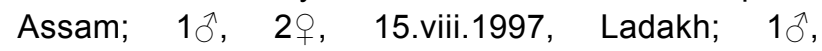
18.viii.1997, Dumkhal, Ladakh; 30, 25.vii.1998, Kargil road, Ladakh; 10, 18.v.2012, Bilaspur, Himachal Pradesh; 5^, 2ᄋ, 20.viii.2019, Leh, Ladakh, (Coll. Gupta).

Distribution India: Kashmir, Ladakh.

Elsewhere: Pakistan, Europe, America, North Africa, Australia.

Remarks: Pieris rapae is a common species distributed widely from Europe to North America. It is also found in Afrotropical and Australian regions. Bingham (1907) and Antram (1924) described the external morphological characters of this species along with its distribution. Herman (1971) compared the female genitalia of $P$. rapae with European Pieris mannii. Both possess differently shaped signum. In this present work, the external morphological and genitalic characters have been studied in detail, and it has been observed that the male genitalic attributes resembles with the genitalic attributes of male of $P$. canidia with slight differences. Both possess sinuous valve with different shape of the distal end. The aedeagus is broad and arched, and saccus is equally small and broad in both the species. In $P$. rapae, the uncus is with blunt tip whereas in $P$. canidia, it is prominently $Y$-shaped from dorsal view with a pointed tip. In $P$. rapae the costa of the valve is the strongly convex and distal end is slightly broad whereas in $P$. canidia, the valve is sinuous with slightly narrowly rounded and tortuous distal end as compared to $P$. rapae and another species of the genus. In females, the signum is almost rounded with well sclerotized boundaries in $P$. rapae whereas in case of canidia it is somewhat bilobed. 
Pieris melete Menetries, 1857

Common name: Green-veined White

(PLATE-XI to XIV)

Pieris melete Menetries, 1857; Cat. Lep. Petersb. 2: 113.

Pieris aglaope Motschulsky, 1860; Etud. Ent. 9:28.

Synchloe megamera Butler, 1873; Cist. Ent. 1 (7): 173.

Pieris melete Winhard, 2000; Butterflies of the World 10: 29.

Artogeia melete Korb \& Bolshakov, 2011; Eversmannia Suppl. 2:27.

Adult (Male WSF): Forewing dorsal surface white; costa thin but dark black; apex broadly black; large circular dark black spot in area $\mathrm{M}_{3}$ and less dark spot in area $\mathrm{Cu}_{2}$; veins well marked with black. Ventral surface whitish with base and costa little dusted with blackish scales; apex light creamy-yellow; dark black dots in area $\mathrm{Cu}_{2}$ and $\mathrm{M}_{3}$. Hindwing dorsal surface white; dark black spot at the apex; veins well marked with black. Ventral surface yellowish-white with veins darker with black.

Adult (Male DSF): Forewing dorsal surface white; costa little blackish; apex black; spots in areas $\mathrm{Cu}_{2}$ and $M_{3}$ absent. Ventral surface white with dark black veins. Hindwing dorsal surface white; without maculation. Ventral surface yellowish-white with darker veins.

Adult (Female DSF): Forewing dorsal surface creamish-white with wider and brownish-black markings; costa and base of the cell brownish-black; apex and termen up to vein $\mathrm{Cu}_{1}$ blackish; dorsum dusted with brownish-black scales and joins the brownishblack spot in area $\mathrm{Cu}_{2}$; the dark brownish-black dot in area $M_{3}$. Ventral surface as in male. Hindwing dorsal surface creamish-white with dark blackish veins; dark blackish spot in area Rs. Ventral surface as in male.

Adult (Female WSF): Both the wings with dorsal side white. Markings are similar as in the female of DSF but less dark and dusted with black scales. Forewing dorsal side base and half of the cell dusted with blackish scales.

Wing-span:55-60 mm.

Male Genitalia (WSF): Uncus broad proximally, slightly arched from middle to a distal end, distal tip pointed, downcurved, V-shaped from dorsal view; tegumen well sclerotized, U-shaped from dorsal view; vinculum sclerotized, sinuous; saccus broad, distal end broadly rounded; juxta reduced cone, upper part U-shaped; valva broad, distal tip rounded marginal area sparsely setosed; aedeagus small, broad, robust, suprazone slightly longer than subzone, subzone much sclerotized, thecal appendage broad, ventral, square-shaped, ductus ejaculatorious dorsad.

Male Genitalia (DSF): Similar as in the male of WSF but the distal part of the uncus is slightly humped in DSF.

Female Genitalia (DSF): Corpus bursae large, balloon-shaped, narrow towards ductus bursae; signum very long, bilobed, inverted heart-shaped with extremely long tail, outer margins bear spines and more sclerotized; appendix bursae very small, rounded; ductus bursae small; papilla analis setosed; posterior apophysis thin, curved, sclerotized, blunt and slightly swollen ends; anterior apophysis smaller than posterior apophysis, broad, much sclerotized, blunt ends, genital plate bilobed.

Female Genitalia (WSF): Similar to as in the female of DSF with slight differences. Corpus bursae spherical; signum long, bilobed, inverted heart-shaped with a small tail; posterior apophysis straight with blunt distal ends.

\section{Material examined:}

5ð (DSF), 14.iv.2017, Lawngtlai, Mizoram, (Coll. Manpreet Kaur); 3ㅇ, 16.iv.2017, Zotlang, Mizoram, (Coll. Manpreet Kaur); 4ð (WSF), 19.iv.2017, Reiek, Mizoram; 19 (DSF), Ilwas, Chamba.

Distribution India: Uttarakhand, Manipur, Meghalaya, Arunachal Pradesh, Assam, Nagaland, Mizoram and Sikkim.

Elsewhere: China, Korea, Manchuria, Japan.

Remarks: $P$. melete Menetries is a common species distributed in North-East India. Evans (1932) and Talbot (1939) described it as P.napi Linnaeus commonly called as European Green veined. Menetries (1857), Gasse (2013) and Varshney (2015) discussed it as $P$. melete including its morphological attributes and distributional range. Lamas (2008) and Kunte et.al. (2020) described it as P. melete and stated that $P$. napi is distributed in the Europe, North and West Asia excluding India and the Oriental region. In this present work, the morphological characters, genitalic attributes and distribution of $P$. melete is studied. The morphological and genitalic characters of both the sexes of DSF and WSF have been studied, illustrated and compared for the first time in this work. Morphologically, both forms are different. In WSF, the apical black border is slightly broad, forewing dorsal side with a black spot in area $M_{3}$, hindwing dorsal side with black costal spot and forewing ventral side with black spot in area $\mathrm{M}_{3}$ and $\mathrm{Cu}_{2}$ whereas in DSF, the apical black border is narrow and there is no black spot on both the sides of both the wings. The genitalic attributes of both the forms are almost similar with a slight difference in their uncus. In DSF, the distal part of the uncus is slightly humped. In the female genitalia, signum is longer than broad, inverted heart-shaped with a long tail 
and the appendix bursae is very small as compared to other Indian species of the genus. In females, the corpus bursae is balloon-like, signum very long with the extremely long tail and posterior apophysis curved in DSF whereas in WSF, the corpus bursae are spherical, signum long with a small tail and posterior apophysis almost straight. The Pieris melete has been recorded for the first time from Ilwas, Chamba. There is no previous record of this species from Chamba, Himachal Pradesh.

\section{Pieris extensa Poujade, 1888}

Common name: Extended White (PLATE-XV)

Pieris erutae Poujade, 1888; Bull. Soc. Ent. Fr. (6) 8: 19.

Pieris eurydice Leech, 1891; Entomologist 24: 5.

Pieris extensa Winhard, 2000; Butterflies of the World 10: 29.

Adult (Male): Forewing dorsal surface white; wellmarked brownish-black veins; costa thin black; apex and termen black up to vein $\mathrm{Cu}_{1}$; the inner margin of black area uneven; whitish quadrate spot in area $M_{3}$. Ventral surface white; costa brownish dusted with light mustard yellow; apex and termen light mustard yellow up to vein $\mathrm{Cu}_{1}$; veins thick brownish. Hindwing dorsal surface white; black subapical dot; veins strongly black. Ventral surface ochraceous yellow with dark brown veins; veins broader near the cell.

Wing-Span: $75-80 \mathrm{~mm}$.

Male Genitalia: Uncus slender, slightly pointed tip, V -shaped from dorsal view; tegumen sclerotized, longer than uncus, broader anteriorly, gradually narrows towards uncus, somewhat U-shaped from dorsal view; vinculum broad, sclerotized, slightly incurved; saccus short, broad, dorso-ventrally flattened; juxta reduced cone; valva tortuous, distal end broadly rounded, marginal area hirsute with small to mediumsized setae; aedeagus extremely short, sinuous, subzone smaller than suprazone, blunt apically, thecal appendage ventral, short, distal end broadly rounded, ductus ejaculatorious dorso-caudad.

Material examined: ZSI, Kolkata, National Museum Collections.

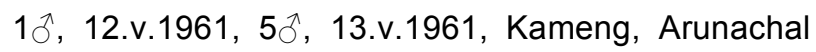
Pradesh.

Distribution India: Arunachal Pradesh.

Elsewhere: West China, Fukien.

Remarks: Pieris extensa Poujade is a rare butterfly distributed in India, West China and Fukien. Leech (1819) described this species as Pieris eurydice and compared its external morphological characters with Pieris melete Menetries. Talbot (1939) reported $P$. eurydice as a darker form of P.extensa and also included its nominotypical form, which is comparatively smaller and with reduced black markings. In this present research, the male external morphological char- acters and male genitalia have been studied, illustrated and compared with P.melete and other members of the group for the first time and it has been observed that it morphologically closely resembles with the DSF of $P$. melete with slight differences. Both the species possess dark veins and black apex. The species $P$. extensa is large in size with a black spot in area $\mathrm{M}_{3}$ and the forewing apex of the ventral side and hindwing ventral side yellow whereas the $P$. melete is smaller in size and forewing apex of the ventral side and hindwing ventral side whitish-yellow. In both the species the valve is with a broadly rounded distal end but in $P$. extensa slightly long and sinuous. The saccus is extremely small, and aedeagus is narrow in both the species as compared to other Indian species of this genus. The aedeagus is more sinuous and narrow in $P$. extensa whereas in $P$. melete it is slightly broad and strongly arched. Uncus slightly resembles the uncus of Pieris brassicae. From the study of male genitalia, it is clear that $P$. extensa and $P$. melete are quite distinct species, though morphologically resemble with each other as advocated by Leech (1819) and Talbot (1939)

\section{Conclusion}

In the present studies, six species of the genus Pieris Schrank have been studied taxonomically from India. The male genitalia of all the species has been studied whereas the female genitalia of four species has been studied. Further, the variable forms, i.e. dry and wet season forms of species Pieris melete has been studied morphologically and dissected for comparing their genitalia. Similarly, the subspecies of $P$. canidia have also been studied morphologically and their genially compared. The comparison of the genitalia of various forms reveals that the structure of male and female genitalia within species is quite stable, showing no variations and considerably distinct from other species. On the basis of male genitalia, it can be concluded that in the genus Pieris in the male genitalia the uncus is undivided and aedeagus is short and thick, whereas in the female genitalia the signum is bifid and appendix bursae are well developed. On comparison of the male genitalia, it has been found that species $P$. brassicae and $P$. deota form a distinct group where the valva bears apical projection and the aedeagus bears middle hump, in all the remaining species the valva is entire and adeagus is without hump.

\section{REFERENCES}

1. Antram, C.B. (1924). Butterflies of India. Thacker, Spink \& Co. Calcutta and Simla.

2. Bingham, C.L. (1907). The fauna of British India including Ceylon and Burma. Taylor and Francis Ltd., London. 
3. Evans, W.H. (1932). The identification of Indian Butterflies. (2nd Edition). The Bombay Natural History Society, Mumbai, India.

4. Gasse, P.V. (2013). Butterflies of India-Annotated Checklist. Retrieved from http://www.ifoundbutt erf lies.org/Checklists.

5. Herman, J.L.T.S. (1971). Some notes on the female genitalia of Pieris rapae Linnaeus and Pieris manni Mayer (Lepidoptera: Pieridae). Stammaeshaus Entomologische Berichten, 31: 13-16.

6. Klots, A.B. (1931). Generic Revision of the Pieridae, together with a study of the male genitalia. Entomologica Americana, 12: 139.

7. Kunte, K., Veino, J. and Veino, D. (2020). Butterflies of India, v. 2.76. http://www.ifoundbutterflies.org.

8. Lamas, G. (2008). Systematic research on diurnal but- terflies (Lepidoptera : Hesperoidea and Papilionoidea): present knowledge and future perspectives. In $\mathrm{J}$. Llorente-Bousquets \& A. Lanteri (eds.), Contribuciones taxonomicas en ordenes de insectos hiperdiversos. Las prensas de Ciencias, UNAM. mexico D. F. : 57-70.

9. Leech, J.H. (1819). New species of Lepidoptera from China. Entomologist, 24: 5.

10.Talbot, G. (1939). The fauna of British India including Ceylon and Burma. Taylor and Francis Ltd., London.

11.Varshney, R.K. and Smetacek, P. (2015). A Synoptic Catalogue of the Butterflies of India. Butterfly Research Centre, Bhimtal and Indinov Publishing, New Delhi, pp 261.

12.Verity, R. (1919). Seasonal Polymorphism and Races of some European Grypocera and Rhopalocera. Ent. Rec. J. Var, 31: 88. 